\title{
HYPOTHALAMIC CONTROL OF SECRETION AND RELEASE OF PROLACTIN
}

\author{
J. S. TINDAL \\ National Institute for Research in Dairying, \\ Shinfield, Reading RG2 9AT
}

When considering the effects of the pituitary trophic hormones, in most cases one thinks in terms of a single target tissue and a single action, such as ACTH and the adrenal cortex or TSH and the thyroid. Prolactin, however, presents a completely different picture. At the most recent census (Nicoll \& Bern, 1971) eighty-two different actions on a variety of target organs were claimed for prolactin throughout the vertebrates. Despite this diversity of action, the environmental and internal stimuli which trigger release of prolactin are far fewer in number, while the final release mechanism, involving hypothalamus, portal system and pituitary, is probably common to most vertebrates, save for the emphasis on hypothalamic facilitation, rather than inhibition, of release in the birds (see later), and for the teleosts where the adenohypophysis receives a direct innervation from the hypothalamus (see Zambrano, Nishioka \& Bern, 1972). Various aspects have been the subject of extensive reviews (Meites, 1970, 1972; Cowie \& Tindal, 1971; Nicoll, 1971 ; Nicoll \& Bern, 1971; Meites \& Clemens, 1972; Grosvenor \& Mena, 1974). Despite the many advances in recent years of our knowledge concerning the physiology and pharmacology of the cultured pituitary and of the median eminence, and of circulating levels of prolactin, the central mechanisms which decide whether or not prolactin will be released remain obscure. Several fragmentary pieces of information do exist, however, and the purpose of this review is to investigate whether they are sufficient to complete this particular puzzle.

\section{HYPOTHALAMIC FACTORS}

It has been known for many years that when the mammalian adenohypophysis is disconnected from the brain, either in vivo or in vitro, it can secrete considerable amounts of prolactin, but not the other trophic hormones. A wealth of studies, involving the use of hypothalamic extracts in various degrees of purity, has made it clear beyond all reasonable doubt that whereas the other trophic hormones are controlled essentially by releasing factors (releasing hormones), the control of prolactin secretion is by means of a prolactin-inhibiting factor, PIF, whose structure is unknown (see Meites \& Clemens, 1972). Evidence has also been put forward to suggest the presence of a prolactin-releasing factor, PRF (Nicoll, Fiorindo, McKennee \& Parsons, 1970), and claims have recently been made for PRF activity in extracts of porcine and rat hypothalamic tissue (Valverde, Chieffo \& Reichlin, 1972). There is little agreement at the moment on where PIF or PRF activity is to be found in the hypothalamus. One report (see McCann \& his co-authors, 1973) puts PIF activity in the 
lateral preoptic area, with PRF activity in the medial basal hypothalamus, while another (Chen, King, Pattison \& Fedde, 1972) claims that PIF activity is to be found in a diffuse area in the medial hypothalamus, whereas PRF activity is found in the preoptic area and lateral and posterior hypothalamic areas. It seems likely that PIF is at least stored in the median eminence, since lesions in this region readily cause release of prolactin (Chen, Amenomori, Lu, Voogt \& Meites, 1970). Birds appear to have the reverse situation to mammals for the regulation of prolactin secretion, since the autonomous avian pituitary does not have the ability to secrete prolactin, and hypothalamic extracts enhance, rather than inhibit, prolactin release by the cultured pituitary (see Cowie \& Tindal, 1971).

\section{MECHANISM OF ACTION OF PIF}

Recent studies have led to a better understanding of the mechanisms involved in the release of hormone granules from adenohypophysial cells and the subject has been extensively reviewed (see Geschwind, 1970; McCann, 1971; Nicoll, 1971). The current view is that the trophic cell membrane is electrically charged and can be depolarized or hyperpolarized. It is believed that depolarization is associated with hormone release and hyperpolarization with inhibition of release (see McCann \& Porter, 1969; McGann, 1971). While trophic cells other than lactotrophs appear to require the presence of a hypothalamic releasing factor for depolarization and hormone release to occur, the lactotroph appears to depolarize spontaneously unless it is hyperpolarized, and therefore inhibited from releasing prolactin, by PIF. The presence of $\mathrm{Ca}^{++}$(Parsons, 1969, 1970) is essential for prolactin release to occur, and $\mathrm{Ca}^{++}$must enter the cell before prolactin granules can leave. To explain the action of releasing factors it has been proposed (see McCann, 1971) that they act on specific receptor sites on the trophic cell membrane and activate the adenyl cyclase-cyclic AMP system. This is believed to cause a change in the permeability of the membrane, allowing $\mathrm{Ca}^{++}$to enter the cell which, in turn is followed by release of the hormone granules. In the case of PIF it is believed that there is a PIF-membrane interaction (Parsons \& Nicoll, 1971). Presumably this factor reduces adenyl cyclase activity and cyclic AMP levels which renders the cell membrane impermeable to $\mathrm{Ca}^{++}$and hence prevents release of prolactin. It has also been tentatively suggested that if granule migration and release is brought about by contraction of a microtubule system within the cell, then the action of $\mathrm{Ca}^{++}$might be to activate a myosin ATPase on the microtubules, leading to contraction of an actomyosin system (McCann, 1971). In the light of recent work, however, the action of releasing factors may not be quite as simple as this, since York, Baker \& Kraicer (1973) found that while infusion of hypothalamic extract in vivo caused transient alterations in transmembrane potentials in only a few adenohypophysial cells, it caused a consistent and reproducible increase in membrane resistance in the majority of cells. It was suggested that adenohypophysial cells may be coupled with low-resistance intercellular bridges, and that releasing factors may function to uncouple cells. York et al. (1973) point out that it is known that intracellular injection of $\mathrm{Ca}^{++}$interrupts intercellular communication and that 
their results are compatible with a model of intercellular communication proposed by Loewenstein (1967) in which a high permeability intercellular communication junction develops when cells come in contact with each other, and which is reversibly dependent on the trans-membrane $\mathrm{Ca}^{++}$gradient. Permeability through the junction falls following intracellular injection of $\mathrm{Ca}^{++}$, causing an interruption in intercellular communication (Loewenstein, 1967; Loewenstein, Nakas \& Socolor, 1967).

Whatever the detailed mode of action of releasing factors may be, the systems which have been described above might afford some explanation for the ability of the isolated pituitary to continue secreting prolactin. In the intact animal it is difficult to decide how important a PRF may be for normal prolactin release, until PIF has been isolated, characterized and synthesized. Terkel, Blake \& Sawyer (1972) observed that an acute stress such as ether elicits a very rapid but relatively small release of prolactin, while the natural stimulus of suckling causes a slightly delayed, but much larger, release of prolactin and that while nicotine blocks suckling-induced release of prolactin, it does not block release of prolactin in response to ether stress (Blake \& Sawyer, 1972a). They suggested that two separate mechanisms exist for prolactin release and that while a specific PRF may be involved in the relatively minor acute releases, the more prolonged release in response to suckling may well be due to inhibition of PIF activity, a conclusion which is in agreement with earlier studies (Ratner \& Meites, 1964; Grosvenor, 1965b; see Cowie \& Tindal, 1971). Valverde et al. (1973) also concluded that release of prolactin caused by ether stress was by means of PRF. In general terms, it does seem likely that the normal mechanism for prolactin release could well be inhibition of release of PIF, without invoking the necessity for a PRF. If the pituitary cells are bathed in a constant trickle of PIF sufficient to maintain hyperpolarization and prevent $\mathrm{Ca}^{++}$entry into lactotrophs (Parsons \& Nicoll, 1971), and if the supply of PIF were temporarily arrested by a suitable stimulus such as suckling, this would allow a burst of prolactin release to occur. It should be mentioned that synthetic thyrotrophin-releasing factor (TRF) also has the inherent ability to cause release of prolactin in man (Bowers, Friesen, Hwang, Guyda \& Folkers, 1971; Jacobs, Snyder, Wilber, Utiger \& Daughaday, 1971; Tyson, Friesen \& Anderson, 1972), sheep (Debeljuk, Arimura, Redding \& Schally, 1973; Kann, Habert \& Denamur, 1973), goat (I. C. Hart, personal communication) and cow (Schams, 1972; Convey, Tucker, Smith \& Zolman, 1973), but not, apparently, in the rat (Lu, Shaar, Kortright \& Meites, 1972).

\section{BIOGENIC AMINES AND PROLACTIN SECRETION}

For some years it has been clear that hypothalamic monoamines have an important rôle to play in the control of anterior pituitary function. Great impetus was given to research in this field by the development by Swedish workers of the histofluorescence technique for the cellular identification of ascending monoaminergic pathways in the brain and their terminal distribution in the hypothalamus (Carlsson, Falck \& Hillarp, 1962; Fuxe, 1963, 1964; Andén, Dahlström, Fuxe, Larsson, Olson \& Ungerstedt, 1966). Monoamines were found to be concentrated in nerve terminals which converge on the 
primary plexus of the pituitary portal system. There are still conflicting views, however, on the finer details of fibre terminations in the median eminence, one group claiming that noradrenaline is concentrated in the external layer and dopamine mainly in the internal layer of the median eminence (Björklund, Falck, Hromek, Owman \& West, 1970), while another group claims the reverse to be the case (Jonsson, Fuxe \& Hökfelt, 1972). The study of Jonsson et al. (1972) included the effects of hypothalamic deafferentation, and the evidence points strongly to a dopaminergic innervation of the external layer of the median eminence originating in cells of the arcuate nucleus and the anterior periventricular hypothalamic nucleus (Björklund, Moore, Nobin \& Stenevi, 1973; Björklund \& Nobin, 1973), and a noradrenergic innervation of the internal layer of the median eminence and throughout the hypothalamus and preoptic area in general, from cell bodies further away in the hypothalamus or even entirely outside the hypothalamus, probably in the pons and medulla (Andén et al., 1966; Fuxe \& Hökfelt, 1970; Jonsson et al., 1972). A serotoninergic pathway ascends from the mesencephalon in company with the ventral noradrenaline path in the medial forebrain bundle and a feature common to both systems is a large network of collaterals (see Ungerstedt, 1971). The serotoninergic (5-hydroxytryptamine, 5-HT) system terminates diffusely in the hypothalamus, with a denser innervation of the suprachiasmatic nuclei, medial retrochiasmatic area and anterior median eminence (Fuxe, 1965; see Fuxe \& Hökfelt, 1970; Fuxe, Hökfelt \& Jonsson, 1970).

Although it had been suggested that the monoamines might act as trophinreleasing or inhibiting factors and that dopamine or noradrenaline might, in fact, be PIF, more recent work has discounted this view, in particular the elegant studies in which amines were introduced either into the third ventricle or into the pituitary portal blood system. By this means it was shown that intraventricular dopamine increased the concentration of PIF in pituitary stalk plasma, reduced plasma prolactin levels and raised plasma $\mathrm{LH}$ and FSH levels, whereas injection of dopamine directly into the portal system was without effect (Kamberi, Mical \& Porter, 1970a, b, 1971a). In agreement with these results were the findings that systemic administration of $\mathrm{L}$-dopa (which passes the blood-brain barrier) depressed serum prolactin level, increased hypothalamic PIF content and evoked the presence of prolactin-inhibiting activity in the serum of the rat ( $\mathrm{Lu} \&$ Meites, 1972) and led to a decrease in serum prolactin levels and a cessation of galactorrhoea in eleven out of fourteen patients suffering from the Forbes-Albright syndrome (Turkington, 1972). In addition, injection of 5-HT or melatonin into the third ventricle of the rat evoked the release of prolactin (Kamberi et al., 1971b). This was confirmed and extended by $\mathrm{Lu} \&$ Meites (unpublished work, quoted by Meites, Lu, Wuttke, Welsch, Nagasawa \& Quadri, 1972), who also found that precursors of 5-HT (tryptophan or 5-hydroxytryptophan) significantly raised serum prolactin levels in rats. Donoso, Bishop, Fawcett, Krulich \& McCann (1971) investigated the action on plasma prolactin levels of various agents which either block or facilitate the synthesis of cerebral amines. They concluded that dopamine is an inhibitory neurotransmitter which suppresses prolactin release, and that elevated levels of noradrenaline may lead to prolactin release. In this connec- 
tion, Kordon, Blake \& Sawyer (1972) reported that blockade of 5-HT synthesis by parachlorophenylalanine (PCPA) blocked the release of prolactin which normally occurs in response to suckling in the rat and that the blockade could be overcome by treatment with 5-hydroxytryptophan. However, PCPA blockade of 5-HT synthesis was without effect on resting levels of prolactin (see Kordon, 1973) and apparently only blocked prolactin release in response to a neural trigger such as suckling.

It appears, therefore, that the balance between release and inhibition of release of prolactin is mediated by hypothalamic amines, acting via PIF, with dopamine favouring release of PIF and inhibition of prolactin release, and 5-HT, melatonin and possibly noradrenaline operating to cause release of prolactin, perhaps under different conditions. Indeed, the findings reviewed above would suggest that dopamine inhibits prolactin release by maintaining secretion of PIF, that noradrenaline might act through a PRF to achieve minor, acute releases of prolactin, while 5-HT, and possibly melatonin, may inhibit the release or blanket the effect of PIF, leading to the major, prolonged increase in circulating prolactin levels seen, for instance, after suckling or milking. It should be pointed out, however, that these amines are the final neurotransmitters in a chain of events leading to release of hypothalamic factors and hence of trophic hormones, and that they themselves are presumably activated or depressed by appropriate incoming neural and humoral stimuli.

The control of gonadotrophin release is beyond the scope of the present paper; however, mention should be made of an apparent reciprocity of release for certain of the pituitary trophic hormones. Thus, activation of dopaminergic mechanisms in the median eminence leads not only to the release of PIF, but also to the release of $\mathrm{FSH} / \mathrm{LH}$ releasing factors (FRF/LRF), so that a stimulus which activates this mechanism would lead to inhibition of prolactin release and facilitation of gonadotrophin release. Conversely, stimuli which trigger release of prolactin have the reverse effect and tend to suppress gonadotrophin release (see later). This is not an invariable rule, however, since concomitant release of LH and prolactin are known to occur at pro-oestrus in the rat (see Meites et al., 1972).

\section{FEEDBACK CONTROL OF PROLACTIN SEGRETION}

It is now well established that prolactin can exert a negative feedback effect on its own secretion in vivo (see reviews by Cowie \& Tindal, 1971; Meites et al., 1972; Meites \& Clemens, 1972). The phenomenon was first noted in rats carrying transplanted prolactin-secreting tumours (MacLeod, Smith \& DeWitt, 1966; Chen, Minaguchi \& Meites, 1967) and later in animals receiving prolonged systemic administration of prolactin or bearing multiple pituitary transplants (Sinha \& Tucker, 1968; Mena, Maiweg \& Grosvenor, 1968; Welsch, Negro-Vilar \& Meites, 1968). Conclusive proof for the 'short' feedback action of prolactin came from studies with local implants of prolactin in the median eminence of rats, which lowered pituitary prolactin concentration and raised the PIF level of the hypothalamus (Clemens \& Meites, 1968). It was also found that systemically-administered oestrogen is less effective in causing prolactin release in rats bearing median eminence implants of prolac- 
tin, since the prolactin implants apparently raised the threshold for oestrogen action (Welsch, Sar, Clemens \& Meites, 1968). More recently, it has been shown that systemic administration of prolactin to the rat, or the presence of pituitary transplants in the anterior chamber of the eye in the rat, results in activation of dopaminergic terminals in the external layer of the median eminence and it has been suggested that dopaminergic neurons in the median eminence can partly mediate the inhibitory feedback action of prolactin on prolactin secretion by increasing the release of PIF by an axo-axonic effect (Hökfelt \& Fuxe, 1972; Olson, Fuxe \& Hökfelt, 1972).

\section{STIMULI WHICH RELEASE PROLACTIN}

In the mammal, the most effective stimulus for the release of prolactin is the activation of receptors at the base of the teat by suckling or milking (see Tindal \& Knaggs, 1970b; Cowie \& Tindal, 1971). Suckling was first reported to result in depletion of pituitary prolactin content many years ago by Reece \& Turner (1937). This was confirmed in later work (Grosvenor \& Turner, 1958; Sar \& Meites, 1969) and it was also found that the release was accompanied by a depletion of hypothalamic PIF content (Ratner \& Meites, 1964). However, the most direct proof for the release of prolactin in response to suckling or milking has come from radioimmunoassay measurements of circulating prolactin levels in the goat (Johke, 1969, 1970; Bryant, Linzell \& Greenwood, 1970), cow (Johke, 1969, 1970; Schams \& Karg, 1970), rat (Amenomori, Chen \& Meites, 1970; Terkel et al., 1972) and man (Kolodny, Jacobs \& Daughaday, 1972; Tyson et al., 1972). Suckling has been observed to correlate with discharge of granules from the lactotroph cells (Pasteels, 1963; see Cowie \& Tindal, 1971), and the discharge was also correlated with a rise in serum prolactin level, measured by radioimmunoassay (Shiino, Williams \& Rennels, 1972 ) in which the maximum rise was achieved after 15 min suckling.

It should be mentioned that the suckling-induced release of prolactin is accompanied by release of ACTH and corticosterone in the rat (Voogt, Sar \& Meites, 1969), goat and sheep (Denamur, Stoliaroff \& Desclin, 1965), growth hormone in the rat (Grosvenor, Krulich \& McCann, 1968; Tucker \& Thatcher, 1968; Sar \& Meites, 1969) and goat (Hart \& Flux, 1973) and by inhibition of FSH and LH in the rat (Rothchild, 1960; Minaguchi \& Meites, 1967). It is also becoming clear that other tactile stimuli may release prolactin in a minor way. Thus, self-licking of the nipples by the pregnant rat has been shown to lead to a greater degree of mammary development than occurs if licking is prevented (Roth \& Rosenblatt, 1966, 1968), which would indicate a lickinginduced release of prolactin. It has been known for some time that burns or surgery or damage to the chest wall in man can lead to spontaneous galactorrhoea (see Kolodny et al., 1972 for references) and more recently it has been shown that irritation of central ascending pathways also leads to prolactin release (Relkin, 1967; Tindal \& Knaggs, 1969, 1972). Even contact between a lactating rat and her pups after removal of her teats leads to inhibition of ovarian activity, presumably caused by tactile triggering of impulses by deformation through the skin of the severed stumps of peripheral nerves (Moltz, Levin \& Leon, 1969; Zarrow, Johnson, Denenberg \& Bryant, 1973). 
The release of prolactin in the lactating rat, however, is not governed solely by physical contact between mother and young, since other environmental stimuli play a rôle at different stages of lactation. It was first noted by Grosvenor (1965a) that placing a lactating rat over, but not in contact with, her pups could lead to depletion of pituitary prolactin content in the absence of suckling. A comprehensive series of investigations (Grosvenor \& Mena, 1967; Grosvenor, Maiweg \& Mena, 1969, 1970) showed that this response developed in primiparous rats between Days 7 and 14 of lactation, and that this conditionedrelease mechanism could be carried over to an ensuing pregnancy and was operative when tested on Day 7 of the second lactation. The causative stimulus was shown to be olfactory, while visual stimuli could serve in the absence of olfaction (Mena \& Grosvenor, 1971). It is not known whether the effective olfactory stimulus is the general odour emanating from the pups or whether a specific pheromone is involved. Later, the prolactin release mechanism becomes sensitive to a wider range of stimuli and, by Day 21 of lactation, prolactin is released spontaneously by the general stimuli emanating from neighbouring rats and litters in the same room (Mena \& Grosvenor, 1972; Grosvenor \& Mena, 1974). This would explain the paradox of why suckling is apparently unable to deplete pituitary prolactin stores on Day 21 of lactation (Grosvenor \& Turner, 1958). Seen in the light of present knowledge, it is not that suckling is ineffective, but merely that other stimuli had already triggered the release before the experimental suckling episode. In the pregnant mouse a converse type of mechanism appears to operate, in which the odour of a strange male can terminate pregnancy through inhibition of prolactin release (see Parkes \& Bruce, 1961).

While discussing the release of prolactin by suckling, it should be mentioned that there is a discrepancy in the literature concerning the efficacy of the suckling stimulus and the time taken for it to deplete pituitary prolactin stores in the rat. While Grosvenor and his colleagues reported that a 30-min suckling period induced a rapid discharge of pituitary prolactin (Grosvenor, 1965a; Mena \& Grosvenor, 1968), Sar \& Meites (1969) claimed that there was only a gradual fall in pituitary prolactin content during a 3-hr suckling period. More recently, Vodian \& Nicoll (1970, quoted by Nicoll, 1971) obtained results intermediate between these two extremes. Nicoll (1971) pointed out that pituitary prolactin appears to be present in the lactating rat in at least three fractions: one which can be rapidly discharged, one which is more slowly releasable, and one which is essentially non-releasable, and that different proportions of these three fractions may be present in different strains of rat. Nicoll (1971) also calculated that the total pituitary prolactin content of the rats used by Meites's laboratory was only about $25 \%$ of that found in the rats used by Grosvenor's group and concluded that this may also be a factor in the discrepancies between results from the two laboratories.

GENTRAL PATHWAYS CONCERNED WITH RELEASE OF PROLACTIN

It is important to know the pathways by which information concerned with prolactin release reaches the hypothalamus, since the route itself or the region of its termination might yield clues to the triggering mechanism involved 


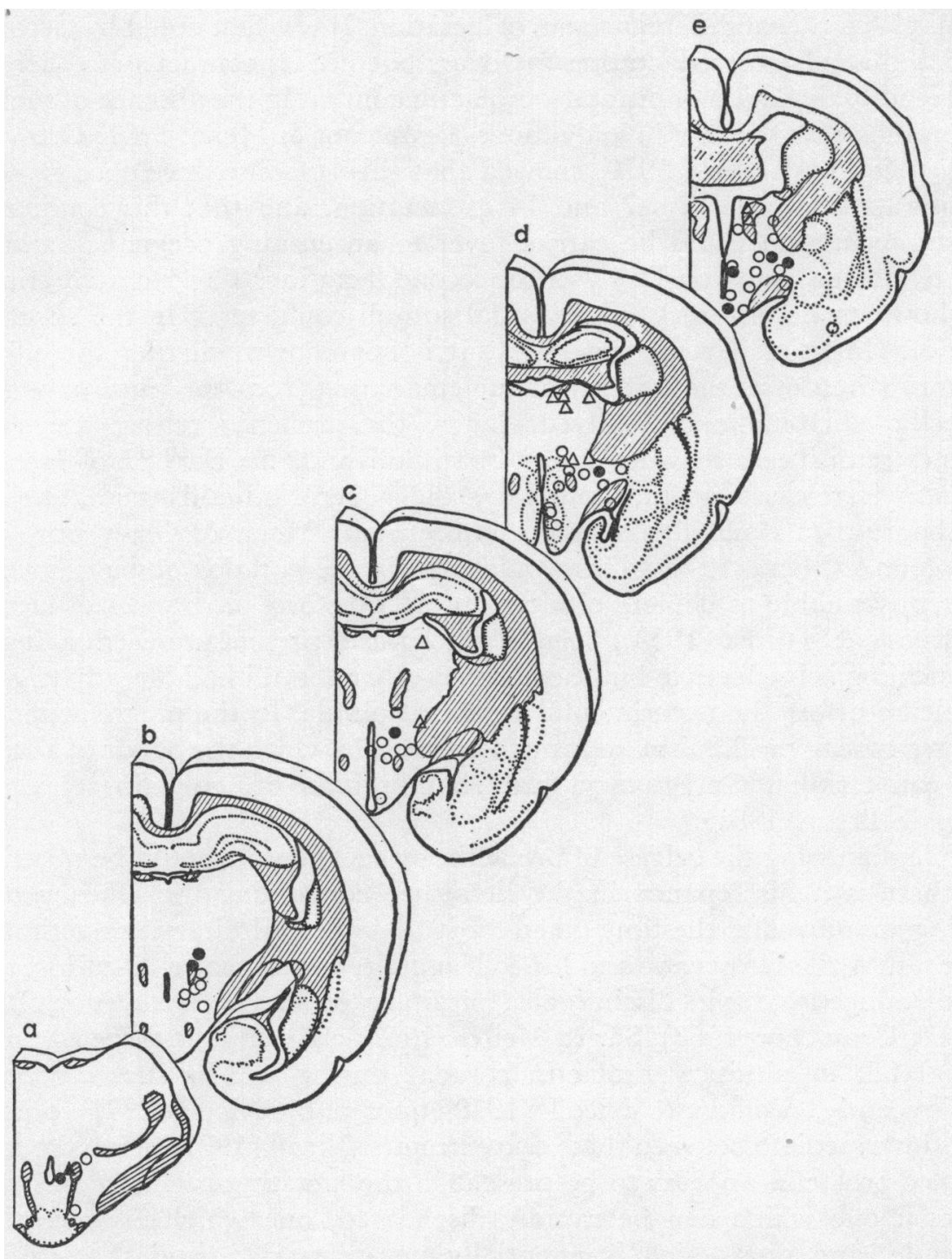

TexT-FIG. 1. Pathways for release of prolactin in the forebrain of the rabbit showing sites where twice-daily electrical stimulation during 11 days of pseudopregnancy caused the release of prolactin and lactogenesis. It was found that control electrode tips, if situated in a pathway for prolactin release, could also evoke release of prolactin by causing irritation of neurones (see Tindal \& Knaggs, 1972). Stereotaxic planes pass rostrally at $1 \mathrm{~mm}$ intervals from Text-fig. 1(a) through to Text-fig. 2(f). Note stimulation sites associated with lactogenesis close to third ventricle in posterior hypothalamus (a) and further rostrally in medio-dorsal $(b, c)$ and then in lateral hypothalamus $(d, e)$ in association with medial forebrain bundle, also two sites near the third ventricle in the anterior hypothalamus (e). - Stimulation followed by lactogenesis; 4 , control electrode, no stimulation followed by lactogenesis; $O$, stimulation, no lactogenesis; $\Delta$, control electrode, no stimulation, no lactogenesis. (From Tindal \& Knaggs, 1972.) 
at the hypothalamic level. In the rabbit, an ascending pathway for prolactin release in the midbrain and forebrain was described by Tindal \& Knaggs (1969, 1970a, 1972). The technique involved electrical stimulation of the conscious, pseudopregnant rabbit through chronically implanted electrodes, and

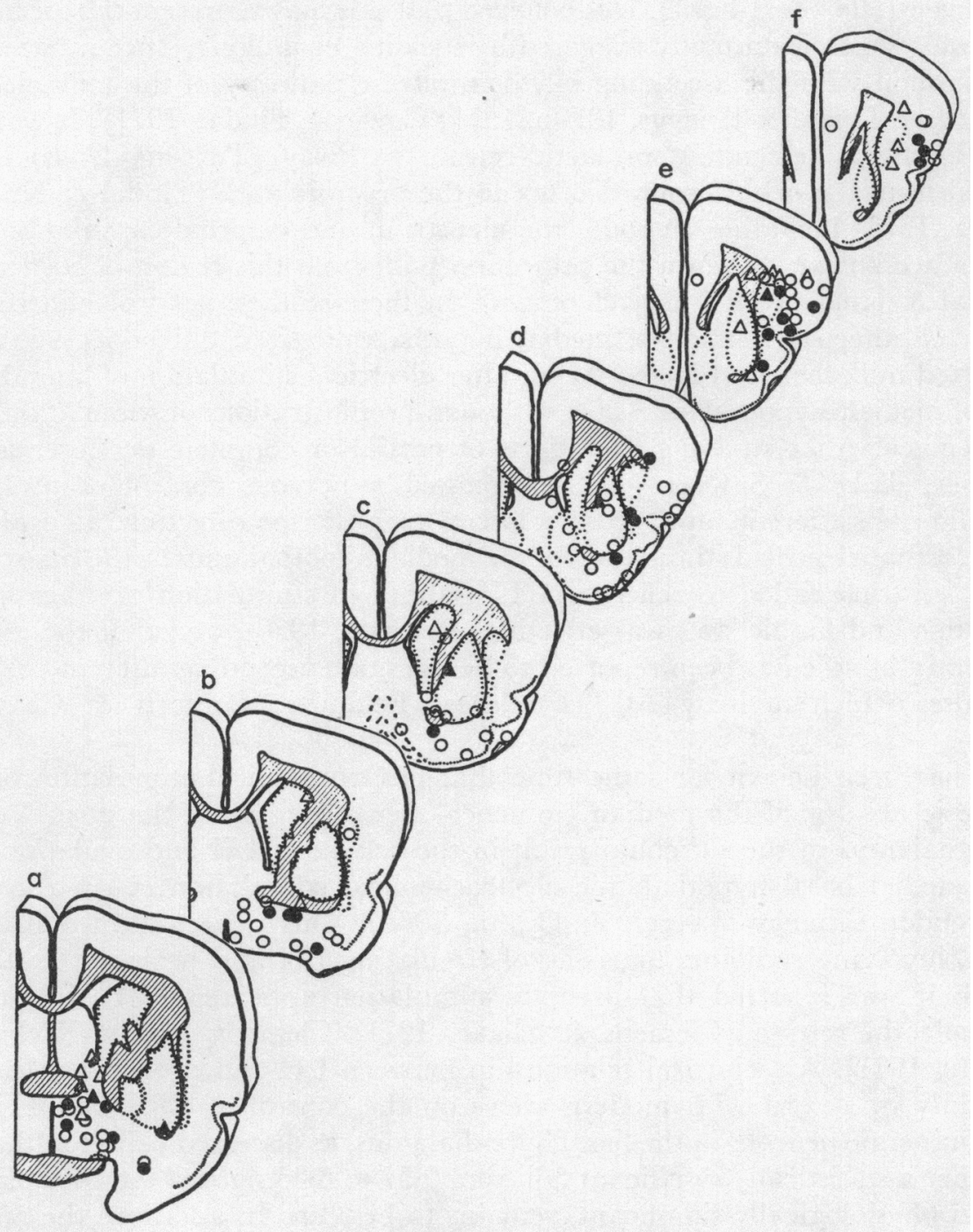

Text-Fig. 2. Pathways for release of prolactin in the forebrain of the rabbit (see legend to Text-fig. 1). Note stimulation sites associated with lactogenesis in lateral and medial preoptic area (a), and further forward in, and ventral to, the external capsule (b, c, d), in the claustrum (d, e) and in the adjacent orbito-frontal cortex $(e, f)$. (From Tindal \& Knaggs, 1972.)

the release of prolactin was assessed at autopsy by the occurrence of lactogenesis. The pathway was situated in the lateral tegmentum in the midbrain and was traced forwards to the posterior hypothalamus where it occupied a site 
midway between the third ventricle and the mammillo-thalamic tract, and from there it passed rostrally in the medio-dorsal hypothalamus, entered the far-lateral hypothalamus within the medial forebrain bundle, and finally passed to the lateral and medial preoptic areas and thence caudally from the medial preoptic area to the medial anterior hypothalamic area, close to the third ventricle (Text-fig. 1). It is believed that this may represent the ascending pathway which is normally triggered by suckling or milking, since it has much in common with the ascending oxytocin-release pathway of the milk-ejection reflex (see Tindal \& Knaggs, 1970b, 1971; Cowie \& Tindal, 1971). It was also found that a descending prolactin-release pathway (Text-fig. 2) could be traced from the orbito-frontal cortex to the preoptic area (Tindal \& Knaggs, $1970 \mathrm{a}, 1972$ ) including en route the claustrum and external capsule, both of which are known to lie on the projection path from this region of cortex (see Tindal \& Knaggs, 1972 for references). In these studies, no prolactin release occurred after stimulation of medial hypothalamic sites. Shikado (1966) also reported milk secretion in the rabbit after electrical stimulation of lateral, but not of medial, hypothalamic sites, although no illustrations of stimulation sites were given. After studying the effects of partial or complete deafferentation, Weiner, Blake \& Sawyer (1972) suggested a nervous control of prolactin secretion via afferent input from a lateral or posterior direction. It is also of interest that electrical stimulation of the medial hypothalamus at the base of the third ventricle failed to release ACTH, although stimulation of other hypothalamic and limbic sites was effective (Redgate, 1970), and that the medial forebrain bundle has been reported to be the main ascending afferent path for impulses which activate ACTH release (Feldman, Conforti \& Chowers, 1971).

It has been known for some time that electrochemical stimulation of the preoptic area or of the median eminence-arcuate region of the medial basal hypothalamus in the rat could result in the release of $\mathrm{LH}$ and ovulation and that medial basal hypothalamic electrochemical stimulation could also lead to pseudopregnancy (Everett \& Quinn, 1966). This was confirmed in later work, involving radioimmunoassay of circulating LH and prolactin levels, in which it was reported that preoptic stimulation appeared to be inhibitory to prolactin release (Clemens \& Shaar, 1971; Clemens, Shaar, Kleber \& Tandy, 1971). A reciprocal relationship between $\mathrm{LH}$ and prolactin release is certainly in accord with modern views on the control of LRF and PIF by dopaminergic neurons in the basal hypothalamus, as discussed earlier, although whether a statistically significant fall from 9.57 to $6.25 \mathrm{ng}$ prolactin $/ \mathrm{ml}$ plasma is also physiologically significant, remains to be seen. In addition, the release of prolactin following electrochemical stimulation of the median eminencearcuate area (Clemens \& Shaar, 1971; Clemens et al., 1971) may not be quite as simple a mechanism as it might appear, since in later work (Clemens, Shaar, Tandy \& Roush, 1971) stimulation of this area in ovariectomized rats failed to release prolactin unless the rats had been pretreated with oestradiol benzoate or oestradiol benzoate plus progesterone, the inference being that the steroids lowered the threshold of appropriate neurons. In contrast to the findings of Clemens and his group, Wuttke \& Meites (1972a) reported that stimula- 
tion of the preoptic area in the rat did cause release of prolactin when applied through chronically implanted electrodes, whereas acute stimulation was ineffective, and Gala \& Lawson (1973) reported no effect on circulating prolactin levels after acute stimulation of neocortex, preoptic area or medial basal hypothalamus. The relatively small releases of prolactin reported by Clemens and his group make it difficult to avoid the conclusion that they may not have been stimulating the major prolactin-release pathway. It is possible that the electrochemical stimulation was activating a minor, rapid-release mechanism, such as can be activated by ether (Terkel et al., 1972), since the release of prolactin triggered by suckling (Terkel et al., 1972) results in a plasma prolactin concentration approximately ten times higher than most of the electrochemical-induced releases reported by Clemens's group. It may be noted that the circulating level of prolactin reported by Terkel et al. (1972) after suckling had a peak value of approximately $250 \mathrm{ng} / \mathrm{ml}$ plasma. These data were similar to the level $(280 \mathrm{ng} / \mathrm{ml}$ serum) reported in lactating rats by Chen $e t$ al. (1970), but were approximately twice as high as that reported by Amenomori et al. (1970) (130 ng/ml serum) who obtained blood samples under ether anaesthesia, although this may possibly reflect strain differences in the pituitary content of prolactin, discussed earlier.

The problems associated with studying trophic hormone release under anaesthesia are only now being appreciated. Thus, pentobarbitone will cause an initial release of prolactin in the rat, supposedly by destroying PIF and subsequently inhibiting release by a direct action on the pituitary (Wuttke \& Meites, 1970; Wuttke, Gelato \& Meites, 1971). Wuttke \& Meites (1972a) suggest that release of prolactin caused by electrochemical stimulation of the pentobarbitone-anaesthetized rat may be a reflection of PRF release, while Ajika, Krulich \& McCann (1972) put forward the idea that pentobarbitone anaesthesia blocks the release of PRF which is released in response to ether stress. Even urethane, which has usually been considered a satisfactory anaesthetic for neuroendocrine studies, has recently been shown to block LRF release and hence LH release and spontaneous ovulation in the rat (Blake \& Sawyer, 1972b). In our own laboratory, after a series of completely negative experiments, it became clear that urethane was probably blocking release of prolactin in the rat in response to electrical stimulation of the brain and the use of urethane has now been discarded in favour of the decorticate rat, prepared initially under brief methohexitone anaesthesia. In the light of present knowledge, it was a fortunate decision to stimulate the conscious rabbit in the earlier studies (Tindal \& Knaggs, 1969, 1970a, 1972) on prolactin-release pathways and these findings, obtained by bioassay, have been confirmed and are now being extended in the rat using radioimmunoassay to determine prolactin levels in the blood (J. S. Tindal \& G. S. Knaggs, unpublished work).

As regards olfactory-mediated inhibition of prolactin release in the mouse and facilitation of release in the rat, discussed earlier, there appears to be a choice of pathways for olfactory information to reach the hypothalamus. It could travel in the medial forebrain bundle direct from the olfactory bulb and tubercle to the lateral preoptic area and lateral hypothalamic area (Scott \& Pfaffmann, 1967) or indirectly, to the pyriform cortex and amygdala and thence 
by the ventral amygdalofugal pathway to the lateral preoptic area (see White, 1965; Powell, Cowan \& Raisman, 1963). The vomeronasal organ, which projects to the amygdala and medial hypothalamus (Winans \& Scalia, 1970), may also be involved.

\section{SPEGULATION ON POSSIBLE CENTRAL NERVOUS CONTROL MEGHANISMS OF}

\section{PROLACTIN RELEASE}

The current evidence indicates that there may be one mechanism involving the inactivation or inhibition of PIF for the major releases of prolactin released by 'natural' stimuli such as suckling or milking, and another mechanism involving a specific PRF for the more rapid, trivial releases associated with minor stresses and traumas (see Terkel et al., 1972). In this connexion, only relatively trivial releases have been reported after electrochemical stimulation of the medial and basal hypothalamus (Clemens \& Shaar, 1971; Clemens Shaar, Kleber \& Tandy, 1971) and major pathways for prolactin (Tindal \& Knaggs, 1970a, 1972) and also for ACTH (Redgate, 1970) release appear to terminate outside this area, in the lateral and anterior hypothalamus and in the preoptic area. The site of manufacture or storage of PIF is still debatable, but in view of the ability of lesions of the arcuate nucleus, ventral part of the ventromedial nucleus and median eminence to cause release of prolactin (Haun \& Sawyer, 1960; Kanematsu, Hilliard \& Sawyer, 1963; Chen et al., 1970; Welsch, Squiers, Cassell, Chen \& Meites, 1971; Bishop, Fawcett, Krulich \& McCann, 1972) it would be surprising if the site of PIF storage was not in this region of the brain. Although a more detailed and systematic study of the hypothalamus is essential to explain the apparent termination of major prolactin-releasing pathways at some distance, apparently, from the median eminence, it has been suggested that there may be a change of transmitter at this point. Thus, incoming stimuli may achieve prolactin release by inhibiting the subsequent neuron or chain of neurons, which themselves may be concerned with the activation of PIF release, and electrical stimulation of this final path would lead, not to increased prolactin release, but to increased PIF release and hence reduced prolactin release (Tindal \& Knaggs, 1972).

In an earlier section, the rôle of biogenic amines was reviewed, in particular the LRF and PIF-releasing action of dopamine. The hypothalamic dopamine neurons are extremely short (they have no connexion with the nigro-striatal path; see Ungerstedt, 1971, for review), having their origin in the arcuateperiventricular region and terminating in the median eminence, so presumably it would be necessary to postulate a preoptic-anterior hypothalamic neuronal link to this basal region. However, there are other routes by which this system could be influenced. It was suggested by Tindal (1967) that the limbic system might modulate basic hypothalamic mechanisms for prolactin release, since prolactin release occurred after local placement of oestrogen in specific regions of the amygdala (Tindal, Knaggs \& Turvey, 1967). Later studies confirmed that these sites were, in fact, preferential sites for uptake of labelled oestrogen (Stumpf \& Sar, 1971; Pfaff \& Keiner, 1972). At the time, existing anatomical knowledge (Ban \& Omukai, 1959) indicated that these oestrogen-sensitive neurons projected to the hypothalamus by the stria terminalis, rather than by 
the ventral amygdalofugal bundle. Rapid technical advances in the tracing of neural pathways have since revealed a complex distribution network of these two amygdaloid projections within the hypothalamus. Heimer \& Nauta (1969) showed that part of the precommissural component of the stria terminalis surrounds the ventromedial hypothalamic nucleus in a shell-like manner, and this nucleus receives further information from the anterior hypothalamus, which itself receives an input from the postcommissural component of the stria terminalis (Chi, 1970). More recently, in an exhaustive investigation, De Olmos \& Ingram (1972) and De Olmos (1972) have described the origin of the different components of the stria terminalis, the relative positions of these components within the stria terminalis, and the termination of these components within the hypothalamus. The fibres of the stria are arranged in a dorsal and a ventral layer. The dorsal stria takes its origin from the caudal portions of the cortical and medial amygdaloid nuclei, and terminates as the precommissural component surrounding the shell of the ventromedial nucleus. The ventral stria provides the postcommissural projection and is divided into medial and lateral divisions by the commissural component. The medial postcommissural component originates in the rostral two-thirds of the cortical and medial amygdaloid nuclei and in the medial part of the basal nucleus, and projects to the entire ventromedial nucleus. The lateral postcommissural stria arises from the lateral, central and basal amygdaloid nuclei and projects to the lateral portion of the bed nucleus of the stria terminalis. The ventromedial nucleus thus receives a dual innervation from the stria terminalis, the precommissural component encompasses the shell, while the postcommissural component innervates the core, and it is of particular interest that the sites of origin of these two components in the amygdala coincide exactly with the oestrogen-sensitive sites involved in prolactin release (Tindal et al., 1967).

In addition, the zone surrounding the ventromedial nucleus has been shown to contain a massive plexus of dendrites, many of which are long, and Heimer \& Nauta (1969) have suggested that these components of the stria terminalis may exert effects on neurons whose cell bodies lie some distance away in the hypothalamus. The presence of these long dendrites suggests the possibility that neurons in the region of the preoptic-anterior hypothalamic boundary whose stimulation caused release of prolactin (Tindal \& Knaggs, 1972) may have done so by acting on dendrites whose cell bodies lay in the ventromedial-arcuate region. The preoptic and anterior hypothalamic areas are situated at the confluence of several major fibre systems connected with the limbic system, mesencephalon and frontal pole of the brain, and are therefore strategically placed to act as an integrator for a final path leading to prolactin release.

Anatomical mapping of amygdalofugal pathways has been matched in recent years by elegant neurophysiological studies on the relationship between the amygdala and the hypothalamus. It has been found that stimulation of ventral amygdalofugal and stria terminalis pathways exerts opposite effects on ventromedial hypothalamic units; stimulating the stria terminalis inhibits, while stimulating the ventral amygdalofugal pathway causes excitation followed by inhibition (Dreifuss, Murphy \& Gloor, 1968; see Dreifuss, 1972). 
However, Murphy, Dreifuss \& Gloor (1968) also issue the caution that the stimulation frequency is important. As the frequency increases, the response of a ventromedial unit can change from facilitation to complete inhibition, and they suggest that the natural rate of impulse transmission may be an important factor in determining whether trans-synaptic effects will be excitatory or inhibitory.

Within the ventromedial nucleus itself, there appear to be two different types of neurons which can be activated by stimulation of the amygdala (Murphy \& Renaud, 1968, 1969; see Murphy, 1972). One type, found mainly at the periphery of the nucleus, is bipolar, while the other, found mainly in the medial and basal portion of the nucleus, is multipolar. The bipolar cells are thought to be inhibitory interneurons which are activated either by the ventral amygdalofugal bundle or the stria terminalis. Thus, in the case of either pathway, a facilitatory signal into the amygdala could result in an inhibitory signal being passed to the multipolar cells within the ventromedial nucleus. These workers consider, therefore, that the amygdala and ventromedial nucleus together may be a hypothalamic control 'centre' in a general sense. While both efferent pathways from the amygdala are excitatory, the intervening bipolar interneuron provides the possibility of an inhibitory function for each pathway, and an inversion module, or polarity switch, is therefore incorporated into both amygdaloid outputs. Tindal (1967) suggested that the amygdala was probably modulating hypothalamic mechanisms of prolactin release and Egger (1972) also considers the amygdala to have a biasing function over the hypothalamus, perhaps even acting as a timing mechanism for certain hypothalamic functions. As regards neuroendocrine function of the amygdala in the deermouse, Zolovick (1972) considers that the baso-lateral part of the amygdala exerts a tonic inhibitory influence over the cortico-medial amygdaloid complex. There may, therefore, be a type of neurophysiological 'balance' between these two parts of the amygdala, and depending on which way the 'balance' swings, so will the ventromedial nucleus be affected.

This apparent digression into recent work on the amygdala and its connections was undertaken because these new findings may, perhaps, hold the key to at least part of the problem under discussion, namely the central control of prolactin release. The two types of cells in the ventromedial hypothalamic nucleus are of particular interest, especially since the multipolar cells appear to be clustered in the medial and basal region of the nucleus. It has been shown that basal hypothalamic lesions in the rabbit, involving the arcuate and basal ventromedial nuclei, can cause release of prolactin (Haun \& Sawyer, 1960; Kanematsu et al., 1963) and one is left with the speculation as to whether these multipolar cells are concerned with PIF secretion themselves, or regulate PIF secretion in neighbouring cells in the arcuate nucleus or median eminence. If this were the case, then the prolactin-releasing action of oestrogen implants in the cortico-medial and medial-basal amygdaloid nuclei (Tindal et al., 1967) could be explained by the inhibitory interneurons 'switching off' PIF release when they were activated by stria terminalis fibres or by a projection from the anterior hypothalamus (Chi, 1970) which itself is associated with inputs from another stria component (Text-fig. 3). In the work of Tindal \& Knaggs (1972), 
the ascending prolactin-release path travelled rostrally until the level of the lateral preoptic area was reached, when it turned medially into the medial preoptic area and appeared to start moving caudally, close to the third ventricle in the anterior hypothalamus. Whether the pathway terminated here, or passed caudally in association with the projection described by Chi (1970) and was not detectable by the available techniques in use at the time, will be resolved by more refined studies utilizing radioimmunoassay of circulating prolactin levels. In addition, the extensive and far-reaching dendritic network referred to earlier (Heimer \& Nauta, 1969) may link ventromedial or arcuate nucleus cells

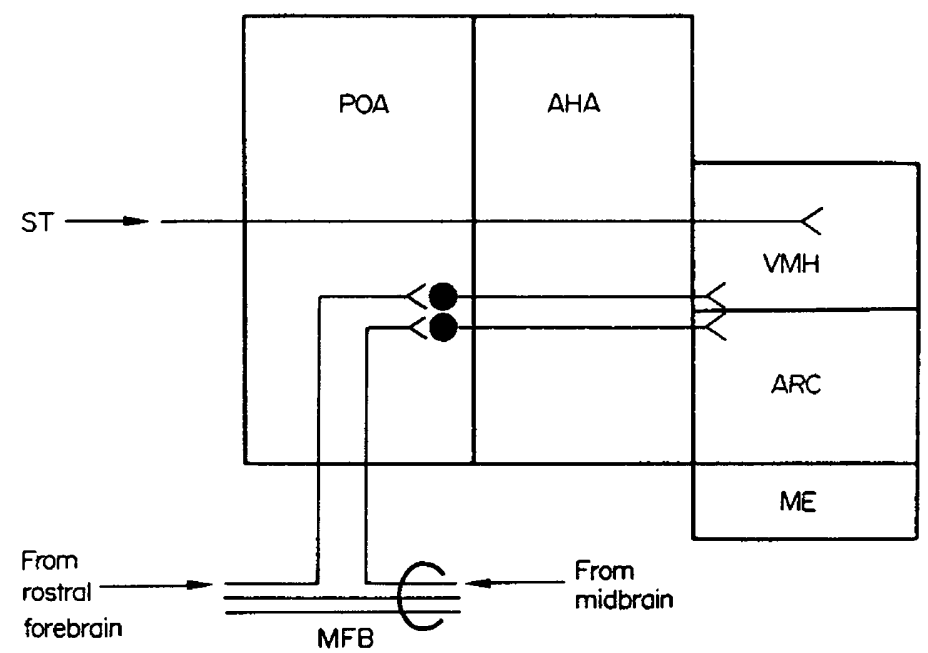

\begin{abstract}
TEXT-FIG. 3. Possible mechanism for major releases of prolactin. Impulses from prolactinreleasing stimuli ascend via spinothalamic tract and medial forebrain bundle or descend from orbital cortex, claustrum, external capsule and part of striatum to enter the preoptic area (Tindal \& Knaggs, 1969, 1972). Stimuli could act at the preoptic level on a subsequent neuron or chain of neurons involved in tonic release of PIF by the basal hypothalamus. It is possible that while the somas of such neurons could lie in the arcuateventromedial region their dendrites might extend rostrally to the preoptic-anterior hypothalamic region (see Heimer \& Nauta, 1969). In either case it is proposed that transmission in these final neurons would be inhibited by prolactin-releasing stimuli, causing a temporary inhibition of PIF release and hence a surge of prolactin release. The mechanism could also be modulated by a specific region of the amygdala acting via the stria terminalis on the ventromedial nucleus (Tindal et al., 1967). AHA, anterior hypothalamic area; ARC, arcuate nucleus; ME, median eminence; MFB, medial forebrain bundle; POA, preoptic area; ST, stria terminalis; VMH, ventromedial nucleus.
\end{abstract}

with those in the neighbouring anterior hypothalamic area, and axons entering this region may make their effective contacts with basal hypothalamic neurons at the axo-dendritic level, rather than at the level of the soma. It appears, therefore, that ascending prolactin-release impulses triggered by tactile stimuli, as well as descending stimuli from orbito-frontal cortex, probably enter the final prolactin-control mechanism at the preoptic-anterior hypothalamic level (Tindal \& Knaggs, 1972).

In general terms, the rôle of the orbital prefrontal cortex in the regulation of hypothalamic mechanisms is not yet clear. It receives a polysensory input (Korn, Wendt \& Albe-Fessard, 1966; Korn \& Richard, 1968) and has wide- 
spread connections with subcortical structures, including the striatum, lateral preoptic and lateral hypothalamic areas and the amygdala (see Tindal \& Knaggs, 1972, for review). More specifically, it does appear to be involved in the release of prolactin (Tindal \& Knaggs, 1972) and it is possible that it may be operative in the conditioned release of prolactin which can occur in the lactating rat in response to certain exteroceptive cues (Grosvenor et al., 1970). Prefrontal cortex has been considered by Akert (1964) to be the superstructure of limbic and visceral activity, while Nauta (1964) even goes as far as to suggest that it may supply the neural code to interpret the environment to the more basic mechanisms of the body. If this prediction is correct, future work should reveal whether the prolactin-release mechanism is one of several hypothalamic mechanisms to receive orders from this part of the neocortex.

\section{GYCLIC RELEASE OF PROLACTIN}

Workers in the field of lactational physiology tend to regard the release of prolactin as being synonymous with specific, randomly-spaced environmental stimuli. However, apart from minor stress-induced releases, discussed earlier, there is evidence for a cyclical pattern of prolactin release. Thus, rat pituitary prolactin content shows a circadian periodicity with a maximum value at 16.00 hours, and a minimum at 22.00 hours (Clark \& Baker, 1964) and a diurnal rhythm in serum prolactin level was also reported to occur in male, intact female and ovariectomized female rats, with higher values in the late afternoon than in the morning, although this conclusion was based on sampling at these two times of day only (Koch, Chow \& Meites, 1971). To talk of a circadian release pattern in the lactating animal is almost a contradiction in terms, since the amount of prolactin released by suckling or milking will swamp any underlying variation. A circadian pattern has been reported in the lactating cow although on examination the data are not very convincing since blood samples were not taken for $30 \mathrm{~min}$ after milking to exclude milking-induced release, and the circadian changes, which were of trivial dimensions, accounted for only $8 \%$ of the total variation in prolactin values (Koprowski, Tucker \& Convey, 1972). Basal levels of circulating prolactin have been measured in lactating and non-lactating virgin and castrated male goats (Hart, 1973). It was shown that although in the non-lactating animals the basal level may slowly rise and fall within a $24-\mathrm{hr}$ period, there was considerable variation between animals, and nothing to suggest a circadian pattern of release. In man, however, a definite circadian release pattern has been demonstrated. Maximum circulating levels of prolactin occurred at night (Nokin, Vekemans, L'Hermite \& Robyn, 1972) and were found to be associated with sleep (Sassin, Frantz, Weitzman \& Kapen, 1972).

During the oestrous cycle of the rat, the ovulatory surge of $\mathrm{LH}$ which occurs on the afternoon of pro-oestrus is accompanied by a release of prolactin (Kwa \& Verhofstad, 1967; Niswender, Chen, Midgley, Meites \& Ellis, 1969; Wuttke \& Meites, 1970). This release of prolactin does not appear to have a direct rôle in ovulation since blockade of prolactin release at this time does not lead to blockade of ovulation (Wuttke, Cassell \& Meites, 1971; Yokoyama, Tomogane \& Ôta, 1972). Studies involving ovariectomy, with and without oestrogen 
replacement therapy (Yokoyama et al., 1971; R. H. Glark \& J. Meites, unpublished work quoted by Meites \& Clemens, 1972), and the use of an antiserum to oestradiol have shown that the oestrogen surge which occurs on the day before pro-oestrus in the rat is responsible for stimulating the pro-oestrous surges of LH and prolactin (Neill, Freeman \& Tillson, 1971). Oestrogen can cause release of prolactin in vivo by acting at the hypothalamic level and reducing PIF content, or by acting directly on the pituitary (for references, see Meites \& Clemens, 1972) and the pro-oestrous surge of prolactin can be duplicated in the adult ovariectomized rat by injection of oestrogen (Neill, 1972). This release of prolactin does not occur, however, after making a retrochiasmatic cut separating the anterior hypothalamus from the tuberal region (Blake, Weiner \& Sawyer, 1972; Neill, 1972). The oestrogen-induced prolactin surge does not occur in males castrated when adult, or in androgensterilized females ovariectomized when adult, and Neill postulated a rostral 'surge centre'. However, it should be pointed out that oestrogen is capable of acting at the level of the amygdala to trigger prolactin release (Tindal et al., 1967), and that the retrochiasmatic cuts would effectively isolate the basal hypothalamus from the several hypothalamic projections of the stria terminalis, described in the previous section.

Although pseudopregnancy in the rat was originally thought to be dependent on the continuous secretion of prolactin (see Freeman \& Neill, 1972), serum prolactin values are elevated for only the first 2 to 3 days after the induction of pseudopregnancy, and then decline to low levels (Kwa \& Verhofstad, 1967; E. Dickerman \& J. Meites, unpublished work, quoted by Meites et al., 1972). Further doubt was cast on the rôle of prolactin by the report that pseudopregnancy could be induced in rats even when the initial rise in serum prolactin was completely prevented by injection of ergocornine (Wuttke \& Meites, 1972b). However, more recent work has shown that, after the initial elevation of circulating prolactin in the $24 \mathrm{hr}$ following cervical stimulation, there is a daily nocturnal surge of prolactin release, beginning at 01.00 hours, peaking at 03.00 to 05.00 hours and terminating at 09.00 to 11.00 hours (Freeman \& Neill, 1972), and this would pass unnoticed if blood samples were taken at other times of day. Freeman \& Neill attempt to explain this nocturnal rise by suggesting " ... that information derived from cervical stimulation is stored in the brain and then 'remembered' during each night, resulting in a surge of prolactin secretion." However, it is possible that a natural circadian release of prolactin may become manifest during pseudopregnancy though it is normally constrained during the oestrous cycle and completely masked during lactation. Clark \& Baker (1964) reported a circadian periodicity in the concentration of prolactin in the rat pituitary, with a maximum concentration at 16.00 hours and a minimum at 22.00 hours. Although both laboratories used a 12-hr light/12-hr dark schedule, that of Freeman \& Neil (1972) was set $1 \mathrm{hr}$ earlier. In the absence of other over-riding factors, therefore, the rat pituitary appears to have a tendency to release prolactin spontaneously in a circadian pattern. It should also be noted that injection of 5-HT or melatonin into the third ventricle will cause release of prolactin in the rat (Kamberi et al., 1971b). Moreover, rats kept in constant darkness have 
lower pituitary prolactin contents and higher circulating prolactin levels than rats kept under a light-dark regimen or in constant light, and this effect does not occur after pinealectomy (Relkin, 1972; Relkin, Adachi \& Kahan, 1972). Donofrio \& Reiter (1972) claimed that the pineal could depress pituitary prolactin levels in the rat, and this may have been a reflection of increased release and raised circulating levels of prolactin.

It is already known that the pineal principles can influence gonadotrophin release at the hypothalamic and midbrain levels. Thus, 5-HT and 5-methoxytryptophol inhibit FSH release, while melatonin and 5-hydroxytryptophol inhibit LH release (see Fraschini \& Martini, 1970). In view of the available evidence it does seem possible that the 'memory' hypothesis of Freeman \& Neill (1972) might be explained in terms of a circadian rhythm of prolactin secretion and release, modulated by pineal principles. The recent report of an early morning surge of prolactin in the male rat which is abolished by pinealectomy (Rønnekleiv, Krulich \& McCann, 1973) would support this view.

If the importance of circadian rhythms of prolactin release is still a matter for conjecture in the mammal, this is certainly not the case in other vertebrates, where recent studies have unfolded a fascinating story. The majority of these studies have been carried out on a North American migrant bird, the whitethroated sparrow, Zonotrichia albicollis, by A. H. Meier and his colleagues. The essence of their findings is that a whole series of reproductive processes, both direct and indirect, appear to be regulated by circadian rhythms of release of prolactin and corticosterone, variations which themselves are regulated and triggered in some way by daylength. Corticosterone induces phases of sensitivity and insensitivity of various tissues to prolactin, and under natural lighting conditions the circadian pattern of release of the two hormones varies with changing daylength as the year progresses. Utilizing these two variables, it has been possible to mimic experimentally the seasonal changes in fat stores, gonadal growth and regression (see Meier, 1969, 1972; Meier \& MacGregor, 1972) and even pre-migratory locomotor activity of either a northerly (spring) or southerly (autumn) orientation (see Discussion following Meier, 1972). Time does not allow a fuller description of these elegant studies, except to point out that a temporal synergism has been demonstrated for prolactin and adrenal steroids in the regulation of fat stores in a fish, a lizard and the pigeon, and in the response of the pigeon crop-sac to prolactin (Meier, Trobec, Joseph \& John, 1971) and that eft water-drive in a spotted newt is subject to marked daily variations in response to prolactin (see Meier, 1972). Prolactin has also been shown to be antimetamorphic in the newt, Taricha torosa (Cohen, Greenberg, Licht, Bern \& Zipser, 1972), and the frog, Rana pipiens, and this activity in the frog is subject to a daily rhythm of effectiveness (see Meier, 1972). In addition to opposing metamorphosis, prolactin stimulates tadpole growth in both these species, again subject to diurnal variations in potency, unlike somatotrophin itself which was of uniform potency throughout the day (see Meier, 1972; Licht, Cohen \& Bern, 1972). Meier (1972) has suggested the possibility that as the phase angle for the circadian release of prolactin alters with the changing photoperiod during spring and early summer, the tadpole matures and then is allowed to metamorphose. 
Although the title of this brief review did not encompass the environmental control of reproduction throughout the vertebrates, it is clear that knowledge gained of the fundamental mechanisms underlying the control of the release of prolactin will lead to a fuller understanding of the much wider field of reproductive endocrinology. There are many tempting avenues to explore.

\section{REFERENCES}

AjIKA, K., KRulich, L. \& McCanN, S. M. (1972) The effect of pentobarbital (Nembutal) on prolactin release in the rat. Proc. Soc. exp. Biol. Med. 141, 203.

AKert, K. (1964) Discussion following Chap. 19, in The Frontal Granular Cortex and Behavior. Eds. J. M. Warren and K. Akert. McGraw-Hill, New York.

Amenomori, Y., Chen, G. L. \& Meites, J. (1970) Serum prolactin levels in rats during different reproductive states. Endocrinology, 86, 506.

Andén, N.-E., Dahlström, A., FuXe, K., Larsson, K., Olson, L. \& Ungerstedt, U. (1966) Ascending monoamine neurons to the telencephalon and diencephalon. Acta physiol. scand. 67, 313 .

Ban, T. \& OmuKaI, F. (1959) Experimental studies on the fiber connections of the amygdaloid nuclei in the rabbit. F. comp. Neurol. 113, 245.

Bishop, W., Fawcert, G. P., Krulich, L. \& McGann, S. M. (1972) Acute and chronic effects of hypothalamic lesions on the release of FSH, $\mathrm{LH}$ and prolactin in intact and castrated rats. Endocrinology, 91, 643.

Björklund, A., Falck, B., Hromek, F., Owman, C. \& West, K. A. (1970) Identification and terminal distribution of the tubero-hypophyseal monoamine fibre systems in the rat by means of stereotaxic and microspectrofluorometric techniques. Brain Res. 17, 1.

BJörklund, A., Moore, R. Y., Nobin, A. \& Stenevi, U. (1973) The organization of tubero-hypophyseal and reticulo-infundibular catecholamine neuron systems in the rat brain. Brain Res. 51,171 .

Björklund, A. \& NoBin, A. (1973) Fluorescence histochemical and microspectrofluorometric mapping of dopamine and noradrenaline cell groups in the rat diencephalon. Brain Res. 51, 193.

Blake, C. A. \& SAWYER, C. H. (1972a) Nicotine blocks the suckling-induced rise in circulating prolactin in lactating rats. Science, $\mathcal{N}$. Y. 177, 619.

BLAKE, C. A. \& SAWYER, C. H. (1972b) Ovulation blocking actions of urethane in the rat. Endocrinology, $91,87$.

Blake, G. A., Weiner, R. I. \& Sawyer, G. H. (1972) Pituitary prolactin secretion in female rats made persistently estrous or diestrous by hypothalamic deafferentation. Endocrinology, 90, 862.

Bowers, G. Y., Friesen, H. G., Hwang, P., Guyda, H. J. \& Folkers, K. (1971) Prolactin and thyrotropin release in man by synthetic pyroglutamyl-histidyl-prolinamide. Biochem. biophys. Res. Commun. 45, 1033.

Bryant, G. D., Linzelx, J. L. \& Greenwood, F. C. (1970) Plasma prolactin in goats measured by radioimmunoassay: the effects of teat stimulation, mating behavior, stress, fasting and of oxytocin, insulin and glucose injections. Hormones, 1, 26.

Carlsson, A., Falck, B. \& Hillarp, N.-A. (1962) Gellular localization of brain monoamines. Acta physiol. scand. 56, Suppl. 196.

Ghen, C. L., Amenomori, Y., Lu, K. H., Voogt, J. L. \& Mertes, J. (1970) Serum prolactin levels in rats with pituitary transplants or hypothalamic lesions. Neuroendocrinology, 6, 220.

Ghen, C. L., King, S. L., Patrison, M. L. \& Fedde, M. R. (1972) Localization of hypothalamic area controlling prolactin release. Fedn Proc. Fedn Am. Socs exp. Biol. 31, 211.

Ghen, G. L., Mrnaguchi, H. \& Mertes, J. (1967) Effects of transplanted pituitary tumors on host pituitary prolactin secretion. Proc. Soc. exp. Biol. Med. 126, 317.

CHI, C. C. (1970) Afferent connections to the ventromedial nucleus of the hypothalamus in the rat. Brain Res. 17, 439.

ClaARK, R. H. \& BAKER, B. L. (1964) Gircadian periodicity in the concentration of prolactin in the rat hypophysis. Science, $\mathcal{N}$.r. 143, 375.

Clemens, J. A. \& Meites, J. (1968) Inhibition by hypothalamic prolactin implants of prolactin secretion, mammary growth and luteal function. Endocrinology, 82, 878.

Gremens, J. A. \& ShaAr, C. J. (1971) Anterior pituitary hormone control sites in the brain. In Influence of Hormones on the Nervous System, p. 356. Ed. D. H. Ford. Karger, Basel.

Glemens, J. A., ShaAr, G. J., Kleber, J. W. \& Tandy, W. A. (1971) Reciprocal control by the preoptic area of LH and prolactin. Expl Brain Res. 12, 250.

Geemens, J. A., ShaAr, C. J., TAndy, W. A. \& Roush, M. E. (1971) Effects of hypothalamic stimula tion on prolactin secretion in steroid treated rats. Endocrinology, 89, 1317. 
Cohen, D. G., Greenberg, J. A., Licht, P., Bern, H. A. \& Zipser, R. D. (1972) Growth and inhibition of metamorphosis in the newt Taricha torosa by mammalian hypophysial and placental hormones. Gen. E compar. Endocr. 18, 384.

Convey, E. M., Tucker, H. A., Smith, V. G. \& Zolman, J. (1973) Bovine prolactin, growth hormone, thyroxine and corticoid response to thyrotropin-releasing hormone. Endocrinology, 92, 471.

Cowie, A. T. \& Tindal, J. S. (1971) The Physiology of Lactation. Arnold, London.

Debeljuk, L., Arimura, A., Redding, T. \& Schally, A. V. (1973) Effect of TRH and triiodothyronine on prolactin release in sheep. Proc. Soc. exp. Biol. Med. 142, 421.

Denamur, R., Stoliaroff, M. \& Desclin, J. (1965) Effets de la traite sur l'activité corticotrope hypophysaire des petits ruminants en lactation. C. r. hebd. Séanc. Acad. Sci., Paris, $260,3175$.

De Olmos, J. S. (1972) The amygdaloid projection field in the rat as studied with the cupric-silver method. In The Neurobiology of the Amygdala, p. 145. Ed. B. E. Eleftheriou. Plenum Press, New York and London.

De Olmos, J. S. \& Ingram, W. R. (1972) The projection field of the stria terminalis in the rat brain. An experimental study. 7. comp. Neurol. 146, 303.

Donofrio, R. J. \& ReIrer, R. J. (1972) Depressed pituitary prolactin levels in blinded anosmic female rats: rôle of the pineal gland. 7. Reprod. Fert. 31, 159.

Donoso, A. O., Bishop, W., FawaetT, G. P., Krulich, L. \& McGanN, S. M. (1971) Effects of drugs that modify brain monoamine concentrations on plasma gonadotropin and prolactin levels in the rat. Endocrinology, 89, 774 .

Dreifuss, J. J. (1972) Effects of electrical stimulation of the amygdaloid complex on the ventromedial hypothalamus. In The Neurobiology of the Amygdala, p. 295. Ed. B. E. Eleftheriou. Plenum Press, New York and London.

Dreifuss, J. J., Murphy, J. T. \& Gloor, P. (1968) Contrasting effects of two identified amygdaloid efferent pathways on single hypothalamic neurons. F. Neurophysiol. 31, 237.

EGGER, M. D. (1972) Amygdaloid-hypothalamic neurophysiological interrelationships. In The Neurobiology of the Amygdala, p. 319. Ed. B. E. Eleftheriou. Plenum Press, New York and London.

EveretT, J. W. \& Quin, D. L. (1966) Differential hypothalamic mechanisms inciting ovulation and pseudopregnancy in the rat. Endocrinology, 78, 141.

Feldman, S., Conforti, N. \& Ghowers, I. (1971) The role of the medial forebrain bundle in mediating adrenocortical responses to neurogenic stimuli. 7 . Endocr. 51, 745.

Fraschini, F. \& Martini, L. (1970) Rhythmic phenomena and pineal principles. In The Hypothalamus, p. 529. Eds. L. Martini, M. Motta and F. Fraschini. Academic Press, New York and London.

Freeman, M. E. \& Neill, J. D. (1972) The pattern of prolactin secretion during pseudopregnancy in the rat: a daily nocturnal surge. Endocrinology, 90, 1292.

Fuxe, K. (1963) Cellular localization of monoamines in the median eminence and in the infundibular stem of some mammals. Acta physiol. scand. 58, 383.

Fuxe, K. (1964) Cellular localization of monoamines in the median eminence and the infundibular stem of some mammals. Z. Zellforsch. mikrosk. Anat. 61, 710.

Fuxe, K. (1965) Evidence for the existence of monoamine neurons in the central nervous system. IV. Distribution of monoamine nerve terminals in the central nervous system. Acta physiol. scand. 64, Suppl. 247, 39.

Fuxe, K. \& Hökfelt, T. (1970) Central monoaminergic systems and hypothalamic function. In The Hypothalamus, p. 123. Eds. L. Martini, M. Motta and F. Fraschini. Academic Press, New York and London.

Fuxe, K., Hökfelt, T. \& Jonsson, G. (1970) Participation of central monaminergic neurons in the regulation of anterior pituitary secretion. In Neurochemical Aspects of Hypothalamic Function, p. 61 . Eds. L. Martini and J. Meites. Academic Press, New York and London.

Gaza, R. R. \& Lawson, D. M. (1973) The influence of electrical stimulation of the rat brain on serum prolactin levels. Experientia, 29, 355.

Geschwind, I. I. (1970) Mechanism of action of hypothalamic adenohypophysiotropic factors. In Hypophysiotropic Hormones of the Hypothalamus: Assay and Chemistry, p. 298. Ed. J. Meites. Williams \& Wilkins, Baltimore.

Grosvenor, C. E. (1965a) Evidence that exteroceptive stimuli can release prolactin from the pituitary gland of the lactating rat. Endocrinology, 76, 340 .

Grosvenor, C. E. (1965b) Effect of nursing and stress upon prolactin-inhibiting activity of the rat hypothalamus. Endocrinology, 77, 1037.

Grosvenor, G. E., Krulich, L. \& McGanN, S. M. (1968) Depletion of pituitary concentration of growth hormone as a result of suckling in the lactating rat. Endocrinology, 82, 617.

Grosvenor, C. E., Matweg, H. \& Mena, F. (1969) Observations on the development and retention during lactation of the mechanism for prolactin release by exteroceptive stimulation in the rat. In Lactogenesis: the Initiation of Milk Secretion at Parturition, p. 181. Eds. M. Reynolds and S. J. Folley. University of Pennsylvania Press, Philadelphia. 
Grosvenor, C. E., Maiweg, H. \& Mena, F. (1970) A study of factors involved in the development of the exteroceptive release of prolactin in the lactating rat. Horm. E Behav. 1, 111.

Grosvenor, G. E. \& Mena, F. (1967) Effect of auditory, olfactory and optic stimuli upon milk ejection and suckling-induced release of prolactin in lactating rats. Endocrinology, 80, 840.

Grosvenor, G. E. \& MENA, F. (1974) Neural and hormonal control of milk secretion and milk ejection. In Lactation, Eds. B. L. Larson and V. R. Smith. Academic Press, New York and London.

Grosvenor, G. E. \& Turner, C. W. (1958) Pituitary lactogenic hormone concentration and milk secretion in lactating rats. Endocrinology, 63, 535.

HART, I. G. (1973) Basal levels of prolactin in goat blood measured throughout a $24 \mathrm{~h}$ period by a rapid double antibody-solid phase radioimmunoassay. F. Dairy Res. 40, 235.

HART, I. G. \& Flux, D. S. (1973) The release of growth hormone in response to milking in the goat during early and late lactation. 7 . Endocr. 57, 177.

HAUn, G. K. \& SAWYER, G. H. (1960) Initiation of lactation in rabbits following placement of hypothalamic lesions. Endocrinology, 67, 270.

Heimer, L. \& Nauta, W. J. H. (1969) The hypothalamic distribution of the stria terminalis in the rat. Brain Res. 13, 284.

HöKFELT, T. \& FUXE, K. (1972) Effects of prolactin and ergot alkaloids on the tubero-infundibular dopamine (DA) neurons. Neuroendocrinology, 9, 100.

Iacobs, L. S., S myder, P. J., Wilber, J. F., Utiger, R. D. \& Daughaday, W. H. (1971) Increased serum prolactin after administration of synthetic thyrotropin releasing hormone (TRH) in man. 7. clin. Endocr. Metab. 33, 996.

Joнke, T. (1969) Prolactin release in response to milking stimulus in the cow and goat estimated by radioimmunoassay. Endocr. jap. 16, 179.

JонкE, T. (1970) Factors affecting the plasma prolactin level in the cow and the goat as determined by radioimmunoassay. Endocr. jap. 17, 393.

Jonsson, G., Fuxe, K. \& HöKrELt, T. (1972) On the catecholamine innervation of the hypothalamus, with special reference to the median eminence. Brain Res. 40, 271.

Kamberi, I. A., Mical, R. S. \& Porter, J. G. (1970a) Prolactin-inhibiting activity in hypophysial stalk blood and elevation by dopamine. Experientia, 26, 1150.

Kamberi, I. A., Mical, R. S. \& Porter, J. C. (1970b) Effect of anterior pituitary perfusion and intraventricular injection of catecholamines and indoleamines on LH release. Endocrinology, 87, 1.

Kamberi, I. A., Mical, R. S. \& Porter, J. G. (1971a) Effect of anterior pituitary perfusion and intraventricular injection of catecholamines on prolactin release. Endocrinology, 88, 1012.

Kamberi, I. A., Mical, R. S. \& Porter, J. G. (1971b) Effects of melatonin and serotonin on the release of FSH and prolactin. Endocrinology, 88, 1288.

Kanematsu, S., Hilliard, J. \& Sawyer, G. H. (1963) Effect of hypothalamic lesions on pituitary prolactin content in the rabbit. Endocrinology, 73, 345.

Kann, G., Habert, R. \& Denamur, R. (1973) Concentrations plasmatiques de la prolactine et de l'hormone tyréostimulante au cours de la traite des brebis: comparaison avec les effets du TRF. C. r. hebd. Séanc. Acad. Sci., Paris, 276, 1321.

Kосн, Y., GHow, Y. F. \& Mertes, J. (1971) Metabolic clearance and secretion rates of prolactin in the rat. Endocrinology, 89, 1303.

Kolodny, R. G., Jacobs, L. S. \& Daughaday, W. H. (1972) Mammary stimulation causes prolactin secretion in non-lactating women. Nature, Lond. 238, 284.

Koprowski, J. A., Tucker, H. A. \& Convey, E. M. (1972) Prolactin and growth hormone circadian periodicity in lactating cows. Proc. Soc. exp. Biol. Med. 140, 1012.

Kordon, C. A. (1973) Effects of drugs acting on brain monoamines and control of gonadotropic secretion. Proc. 4th Int. Congr. Endocr., Washington, 1972. Excerpta Medica Int. Congr. Ser. No. 273, 120.

Kordon, G. A., Blake, G. A. \& Sawyer, C. H. (1972) Participation of serotonin-containing neurons in the suckling-induced rise in plasma prolactin levels in lactating rats. Abstracts of Short Communications, 4th Int. Congr. Endocr., Washington, 1972. Excerpta Medica Int. Congr. Ser. No. 256, 51.

Korn, H. \& Richard, P. (1968) Participation des faisceaux spino-cervico-thalamique et néo-spinothalamique à la transmission des messages somatiques vers le cortex orbitaire du chat. Electroenceph. clin. Neurophysiol. 24, 514.

Korn, H., Wendt, R. \& Albe-Fessard, D. (1966) Somatic projection to the orbital cortex of the cat. Electroenceph. clin. Neurophysiol. 21, 209.

Kwa, H. G. \& Verhofstad, F. (1967) Prolactin levels in the plasma of female rats. F. Endocr. 39, 455.

Light, P., Cohen, D. G. \& Bern, H. A. (1972) Somatotropic effects of mammalian growth hormone and prolactin in larval newts, Taricha torosa. Gen. E compar. Endocr. 18, 391.

Loewenstein, W. R. (1967) On the genesis of cellular communication. Devl Biol. 15, 503. 
Loewenstein, W. R., Nakas, K. \& Socolor, S. J. (1967) Junctional membrane uncoupling. Permeability transformations at a cell membrane junction. F. gen. Physiol. 50, 1865.

Lu, K. H. \& MeITes, J. (1972) Effects of L-dopa on serum prolactin and PIF in intact and hypophysectomized, pituitary-grafted rats. Endocrinology, 91, 868.

Lu, K. H., ShaAr, G. J., Kortright, K. H. \& Meites, J. (1972) Effects of synthetic TRH on in vitro and in vivo prolactin release in the rat. Endocrinology, 91, 1540.

McCanN, S. M. (1971) Mechanism of action of hypothalamic-hypophyseal stimulating and inhibiting hormones. In Frontiers in Neuroendocrinology, 1971, p. 209. Eds. L. Martini and W. F. Ganong. Oxford University Press, New York.

McGann, S. M., Kalra, P. S., Kalra, S. P., Ajika, K., Libertun, C., Gooper, K. J., Fawcett, G. P. \& KRULICH, L. (1973) Control of adenohypophyseal secretion by hypothalamic releasing and inhibiting neurohormones. Proc. 4th Int. Congr. Endocr. Washington, 1972, Excerpta Medica Int. Congr. Ser. No. 273, 107.

McGann, S. M. \& Porter, J. C. (1969) Hypothalamic pituitary stimulating and inhibiting hormones. Physiol. Rev. 49, 240.

Macleod, R. M., Smith, M. G. \& DeWitt, G. W. (1966) Hormonal properties of transplanted pituitary tumors and their relation to the pituitary gland. Endocrinology, 79, 1149.

Meier, A. H. (1969) Diurnal variations of metabolic responses to prolactin in lower vertebrates. Gen. Eீ compar. Endocr., Suppl. 2, 55.

Meier, A. H. (1972) Temporal synergism of prolactin and adrenal steroids. Gen. $\mathcal{E}$ compar. Endocr., Suppl. 3, 499.

Meier, A. H. \& MACGregor, R. (1972) Temporal organization in avian reproduction. Am. Zoologist, 12, 257.

Meier, A. H., Trobec, T. N., Joseph, M. M. \& John, T. M. (1971) Temporal synergism of prolactin and adrenal steroids in the regulation of fat stores. Proc. Soc. exp. Biol. Med. 137, 408.

MerTes, J. (1970) Direct studies of the secretion of the hypothalamic hypophysiotropic hormones (HHH). In Hypophysiotropic Hormones of the Hypothalamus: Assay and Chemistry, p. 261. Ed. J. Meites. Williams \& Wilkins, Baltimore.

Mertes, J. (1972) Relation of prolactin to mammary tumourigenesis and growth in rats. In Prolactin and Carcinogenesis, p. 54. Proc. 4th Tenovus Workshop. Eds. A. R. Boyns and K. Griffiths. Alpha Omega Alpha Publishing Co., Cardiff.

Meites, J. \& Clemens, J. A. (1972) Hypothalamic control of prolactin secretion. Vitams Horm. 30, 166.

Meites, J., Lu, K. H., Wuttke, W., Welsch, C. W., Nagasawa, H. \& Quadri, S. K. (1972) Recent studies on functions and control of prolactin secretion in rats. Recent Prog. Horm. Res. 28, 471.

Mena, F. \& Grosvenor, G. E. (1968) Effect of number of pups upon suckling-induced fall in pituitary prolactin concentration and milk-ejection in the rat. Endocrinology, 82, 623 .

Mena, F. \& Grosvenor, G. E. (197I) Release of prolactin in rats by exteroceptive stimulation: sensory stimuli involved. Horm. Behav. 2, 107.

Mena, F. \& Grosvenor, C. E. (1972) Effect of suckling and of exteroceptive stimulation upon prolactin release in the rat during late lactation. F. Endocr. 52, 11.

Mena, F., Marweg, H. \& Grosvenor, C. E. (1968) Effect of ectopic pituitary glands upon prolactin concentration by the in situ pituitary of the lactating rat. Endocrinology, 83, 1359.

Minaguchi, H. \& Mertes, J. (1967) Effects of suckling on hypothalamic LH-releasing factor and prolactin-inhibiting factor, and on pituitary LH and prolactin. Endocrinology, 80,603.

Mortz, H., Levin, R. \& Leon, M. (1969) Prolactin in the post partum rat: synthesis and release in the absence of suckling stimulation. Science, N.X. 163, 1083.

MuRPhy, J. T. (1972) The role of the amygdala in controlling hypothalamic output. In The Neurobiology of the Amygdala, p. 371. Ed. B. E. Eleftheriou. Plenum Press, New York and London.

Murphy, J. T., Dreifuss, J. J. \& Gloor, P. (1968) Responses of hypothalamic neurons to repetitive amygdaloid stimulation. Brain Res. 8, 153.

Murphy, J. T. \& Renaud, L. P. (1968) Inhibitory interneurons in the ventromedial nucleus of the hypothalamus. Brain Res. 9, 385.

Murphy, J. T. \& Renaud, L. P. (1969) Mechanisms of inhibition in the ventromedial nucleus of the hypothalamus. 7. Neurophysiol. 32, 85.

Naura, W. J. H. (1964) Some efferent connections of the prefrontal cortex in the monkey. In The Frontal Granular Cortex and Behavior, chap. 19. Eds. J. M. Warren and K. Akert. McGraw-Hill, New York.

NeILL, J. D. (1972) Sexual differences in the hypothalamic regulation of prolactin secretion. Endocrinology, 90, 1154.

Neill, J. D., Freeman, M. E. \& Tillson, S. A. (1971) Control of the proestrus surge of prolactin and luteinizing hormone secretion by estrogens in the rat. Endocrinology, 89, 1448.

Nicoll, C. S. (1971) Aspects of the neural control of prolactin secretion. In Frontiers in Neuroendocrinology, 1971, p. 291. Eds. L. Martini and W. F. Ganong. Oxford University Press, New York. 
Nicoll, C. S. \& BeRN, H. A. (1971) On the actions of prolactin among the vertebrates: is there a common denominator? In Lactogenic Hormones, p. 299. Eds. G. E. W. Wolstenholme and J. Knight. Ciba Foundn Symp. No. 130. Churchill Livingstone, Edinburgh and London.

Nicoll, G. S., Fiorindo, R. P., McKennee, G. T. \& Parsons, J. A. (1970) Assay of hypothalamic factors which regulate prolactin secretion. In Hypophysiotropic Hormones of the Hypothalamus: Assay and Chemistry, p. 115. Ed. J. Meites. Williams \& Wilkins, Baltimore.

Niswender, G. D., Chen, G. L., Midgley, A. R., JR, Meites, J. \& Ellis, S. (1969) Radioimmunoassay for rat prolactin. Proc. Soc. exp. Biol. Med. 130, 793.

Nokin, J., Vekemans, M., L'Hermtte, M. \& Robyn, C. (1972) Circadian periodicity of serum prolactin concentration in man. Br. med. $\mathcal{F}$. iii, 561 .

Olson, L., FuXe, H. \& Hökfelt, T. (1972) The effect of pituitary transplants on the tubero-infundibular dopamine neurons in various endocrine states. Acta endocr., Copenh. 71, 233.

PARKes, A. S. \& BRUCE, H. M. (1961) Olfactory stimuli in mammalian reproduction. Science, N.Y. $134,1049$.

Parsons, J. A. (1969) Calcium ion requirements for prolactin secretion by rat adenohypophyses in vitro. Am. F. Physiol. 217, 1599.

Parsons, J. A. (1970) Effects of cations on prolactin and growth hormone secretion by rat adenohypophyses in vitro. F. Physiol., Lond. 210, 973.

Parsons, J. A. \& Nicoll, C. S. (1971) Mechanism of action of prolactin-inhibiting factor. Neuroendocrinology, 8, 213.

Pasteels, J. L. (1963) Recherches morphologiques et expérimentales sur la sécrétion de prolactine. Archs Biol., Liège, 74, 439.

Pfaff, D. W. \& KeIner, M. (1972) Estradiol-concentrating cells in the rat amygdala as part of a limbic-hypothalamic hormone-sensitive system. In The Neurobiology of the Amygdala, p. 775. Ed. B. E. Eleftheriou. Plenum Press, New York and London.

Powell, T. P. S., Gowan, W. M. \& Raisman, G. (1963) Olfactory relationships of the diencephalon. Nature, Lond. 199, 710.

Ratner, A. \& Mertes, J. (1964) Depletion of prolactin-inhibiting activity of rat hypothalamus by estradiol or suckling stimulus. Endocrinology, 75, 377.

REDGATE, E. S. (1970) ACTH release evoked by electrical stimulation of brainstem and limbic system sites in the cat: the absence of AGTH release upon infundibular area stimulation. Endocrinology, 86, 806.

REECE, R. P. \& TuRNer, G. W. (1937) Effect of stimulus of suckling upon galactin content of the rat pituitary. Proc. Soc. exp. Biol. Med. 35, 621.

Relkin, R. (1967) Neurologic pathways involved in lactation. Dis. nerv. Syst. 28, 94.

RELKIN, R. (1972) Effects of variations in environmental lighting on pituitary and plasma prolactin levels in the rat. Neuroendocrinology, 9, 278.

ReLkin, R., AdAchi, M. \& KaHAN, S. A. (1972) Effects of pinealectomy and constant light and darkness on prolactin levels in the pituitary and plasma and on pituitary ultrastructure of the rat. 7. Endocr. 54, 263.

RønNeKLeiv, O. K., Krulich, L. \& MaCann, S. M. (1973) An early morning surge of prolactin in the male rat and its abolition by pinealectomy. Endocrinology, 92, 1339.

Roth, L. L. \& RosenblatT, J. S. (1966) Mammary glands of pregnant rats; development stimulated by licking. Science, N.Y. 151, 1403.

Roth, L. L. \& Rosenblatt, J. S. (1968) Self-licking and mammary development during pregnancy in the rat. F. Endocr. $42,363$.

RoTHсHILD, I. (1960) The corpus luteum-pituitary relationship: the association between the cause of luteotrophin secretion and the cause of follicular quiescence during lactation; the basis for a tentative theory of the corpus luteum-pituitary relationship in the rat. Endocrinology, 67, 9.

SAR, M. \& MErTES, J. (1969) Effects of suckling on pituitary release of prolactin, GH, and TSH in postpartum lactating rats. Neuroendocrinology, 4, 25.

Sassin, J. F., Frantz, A. G., Weitzman, E. D. \& Kapen, S. (1972) Human prolactin: 24 hour pattern with increased release during sleep. Science, $\mathcal{N} . Y .177,1205$.

Schams, D. (1972) Prolactin releasing effects of TRH in the bovine and their depression by a prolactin inhibitor. Horm. metab. Res. 4, 405.

Schams, D. \& KARG, H. (1970) Untersuchungen über Prolaktin im Rinderblut mit einer radioimmunologischen Bestimmungsmethode. Zentbl. VetMed. A17, 193.

ScotT, J. W. \& Praffmann, C. (1967) Olfactory input to the hypothalamus: electrophysiological evidence. Science, $\mathcal{N}$. . . 158, 1592.

Shino, M., Williams, G. \& RenNels, E. G. (1972) Ultrastructural observation of pituitary release of prolactin in the rat by suckling stimulus. Endocrinology, 90, 176.

SHIKado, Y. (1966) Studies on the effects of chronic electrical stimulation of the hypothalamus on the artificial corpora lutea and mammary glands in rabbits. F. Jap. obstet. gynaec. Soc. 13, 168. 
Sinha, Y. N. \& Tucker, H. A. (1968) Pituitary prolactin content and mammary development after chronic administration of prolactin. Proc. Soc. exp. Biol. Med. 128, 84.

Stumpr, W. E. \& SAR, M. (1971) Estradiol concentrating neurons in the amygdala. Proc. Soc. exp. Bio . Med. 136, 102.

Terkel, J., Blake, G. A. \& SAwYer, G. H. (1972) Serum prolactin levels in lactating rats after suckling or exposure to ether. Endocrinology, 91, 49.

Tindal, J. S. (1967) Studies on the neuroendocrine control of lactation. In Reproduction in the Female Mammal, p. 79. Proc. 13th Easter Sch. agric. Sci. Univ. Nott. 1966. Eds. G. E. Lamming and E. C. Amoroso. Butterworths, London.

Tindal, J. S. \& KnagGs, G. S. (1969) An ascending pathway for release of prolactin in the brain of the rabbit. F. Endocr. 45, 111.

Tindal, J. S. \& KNaGgs, G. S. (1970a) Release of prolactin in the rabbit after electrical stimulation of the forebrain. F. Endocr. 48, xxxii.

Tindal, J. S. \& KNaGgs, G. S. (1970b) Environmental stimuli and the mammary gland. Mem. Soc. Endocr. 18, 239.

Tindal, J. S. \& Knaggs, G. S. (1971) Determination of the detailed hypothalamic route of the milkejection reflex in the guinea-pig. F. Endocr. 50, 135.

Tindal, J. S. \& Knaggs, G. S. (1972) Pathways in the forebrain of the rabbit concerned with the release of prolactin. 7. Endocr. 52, 253.

Tindal, J. S., Knaggs, G. S. \& Turvey, A. (1967) Central nervous control of prolactin secretion in the rabbit: effect of local oestrogen implants in the amygdaloid complex. F. Endocr. 37, 279.

Tucker, H. A. \& Thatcher, W. W. (1968) Pituitary growth hormone and luteinizing hormone content after various nursing intensities. Proc. Soc. exp. Biol. Med. 129, 578.

Turkington, R. W. (1972) Inhibition of prolactin secretion and successful therapy of the ForbesAlbright syndrome with L-dopa. 7. clin. Endocr. Metab. 34, 306.

Tyson, J. E., Friesen, H. G. \& Anderson, M. S. (1972) Human lactational and ovarian response to endogenous prolactin release. Science, $\mathcal{N} . r .177,897$.

UNGERSTEDT, U. (1971) Stereotaxic mapping of the monoamine pathways in the rat brain. Acta physiol. scand. 82, Suppl. 367.

Valverde-R., G., Ghiefro, V. \& Reichlin, S. (1972) Prolactin-releasing factor in porcine and rat hypothalamic tissue. Endocrinology, 91, 982.

Valverde-R., G., Chieffo, V. \& Reichuin, S. (1973) Failure of reserpine to block ether-induced release of prolactin: physiological evidence that stress induced prolactin release is not caused by acute inhibition of PIF secretion. Life Sci. 12, 327.

Voogt, J. L., SAR, M. \& MErTEs, J. (1969) Influence of cycling, pregnancy, labor, and suckling on corticosterone-AGTH levels. Am. F. Physiol. 216, 655.

Weiner, R. I., Blake, G. A. \& SAwYer, G. H. (1972) Integrated levels of plasma LH and prolactin following hypothalamic deafferentation in the rat. Neuroendocrinology, 10, 349.

Welsch, G. W., Negro-Vilar, A. \& Mertes, J. (1968) Effects of pituitary homografts on host pituitary prolactin and hypothalamic PIF levels. Neuroendocrinology, 3, 238.

Welsch, C. W., SAR, M., Clemens, J. A. \& MeItes, J. (1968) Effects of estrogen on pituitary prolactin levels of female rats bearing median eminence implants of prolactin. Proc. Soc. exp. Biol. Med. $129,817$.

Welsch, G. W., Squiers, M. D., Gassell, E., Ghen, G. L. \& Metres, J. (1971) Median eminence lesions and serum prolactin: influence of ovariectomy and ergocornine. Am. F. Physiol. 221, 1714.

White, L. E., JR (1965) Olfactory bulb projections in the rat. Anat. Rec. 152, 465.

Winans, S. S. \& Scalia, F. (1970) Amygdaloid nucleus: new afferent input from the vomeronasal organ. Science, N.Y. 170, 330.

WUttke, W., CAssell, E. \& Meites, J. (1971) Effects of ergocornine on serum prolactin and LH, and on hypothalamic content of PIF and LRF. Endocrinology, 88, 737.

Wuttke, W., Gelato, M. \& Mertes, J. (1971) Mechanisms of pentobarbital actions on prolactin release. Endocrinology, 89, 1191.

WuttKe, W. \& Mertes, J. (1970) Effects of ether and pentobarbital on serum prolactin and LH levels in proestrous rats. Proc. Soc. exp. Biol. Med. 135, 648.

Wuttke, W. \& Mertes, J. (1972a) Effects of electrochemical stimulation of the hypothalamus on serum prolactin and LH in rats. Pflügers Arch., Eur. J. Physiol. 337, 71.

WutTke, W. \& MEIrEs, J. (1972b) Induction of pseudopregnancy in the rat with no rise in serum prolactin. Endocrinology, 90, 438.

Yokoyama, A., Tomogane, H. \& ÓTA, K. (1971) Effects of ovariectomy and of oestrogen administration on the decrease in pituitary prolactin content which occurs on the afternoon of pro-oestrus in the rat. Experientia, 27, 1221.

Yokoyama, A., Tomogane, H. \& ÓTA, K. (1972) Ergocornine blockade of the surge of prolactin at proestrus failed to block ovulation in cycling rats. Proc. Soc. exp. Biol. Med. 140, 169. 
York, D. H., BAKer, F. L. \& Kraicer, J. (1973) Electrical changes induced in rat adenohypophysial cells, in vivo, with hypothalamic extract. Neuroendocrinology, 11, 212.

Zambrano, D., Nishroxa, R. S. \& Bern, H. A. (1972) The innervation of the pituitary gland of teleost fishes. Its origin, nature and significance. In Brain-Endacrine Interaction, p. 50. Eds. K. M. Knigge, D. E. Scott and A. Weindl. Karger, Basel.

Zarrow, M. X., Johnson, N. P., Denenberg, V. H. \& Bryant, L. P. (1973) Maintenance of lactational diestrum in the postpartum rat through tactile stimulation in the absence of suckling. Neuroendocrinology, 11, 150.

ZoLovick, A.J. (1972) Effects of lesions and electrical stimulation of the amygdala on hypothalamichypophyseal regulation. In The Neurobiology of the Amygdala, p. 643. Ed. B. E. Eleftheriou. Plenum Press, New York and London. 